\title{
Clarifying the impacts of organizational silence on organizational commitment with controlling the effects of organizational rumors
}

\author{
Mohammad Hozouri ${ }^{a^{*}}$, Mohsen Yaghmaei ${ }^{\mathrm{b}}$ and Hamed Bordbar ${ }^{\mathrm{a}}$
}

${ }^{a}$ MA in Public Administration, Faculty of Management, University of Tehran, Iran

${ }^{b}$ MA in Technology Management, Faculty of Management, University of Allameh Tabatabaei, Iran

\section{H R O N I C L E \\ A B S T R A C T}

Article history:

Received: January 11, 2018

Received in revised format:

March 3, 2018

Accepted: May 9, 2018

Available online:

May 9, 2018

Keywords:

Organization

Organizational commitment

Organizational rumors

Organizational silence

Municipality

\begin{abstract}
Organizational commitment plays an essential role on the success of service businesses as well as municipalities. One of the primary challenges on such firms is to face with rumors and silence, properly. In fact, organizational rumors and silence are two important issues which influence on employees' organizational commitment. This paper studies the relationship between organizational silence and commitment by controlling organizational rumors. The study designs a questionnaire and distributes it among some employees who worked for a municipality firm in Iran. The results indicate that organizational silence had a negative relationship with organizational commitment by controlling organizational rumors. Likewise, without controlling organizational rumors, the impact of organizational silence or organizational commitment was increased, negatively. Also, the research indicates that there was a strong significant relationship between organizational silence and organizational rumors and organizational silence could improve organizational rumors, significantly.
\end{abstract}

\section{Introduction}

Organizational commitment is a very important factor in employees' organizational behavior and organizational returns and committed human force the organization to reach its goals (Kermani, 2011). Within the past 50 years of consecutive studies, researchers have been interested in concepts such as silence and voice. Usually, committed employees provide ideas, information and opinions for constructive methods on job progress and working organizations. Sometimes, these employees express their own ideas and information while in other times, they remain silent and retain their ideas (Zehir \& Erdogan, 2011). On the other hand, employees' organizational commitment is impacted by their silence or lack of silence. In organizations dominated by organizational silence or silence atmosphere, employees' organizational commitment is changed. Organizational silence changes organizational commitment and leads into the emergences of a behavior called organizational rumors. In fact, when employees cannot talk with managers and other employees in an organizational structure and official organizational communications, they select unofficial communications and informal groups which yield to organizational rumors (Mowday et al., 2013). Therefore, organizational rumors are shaped in an unofficial communication context

* Corresponding author.

E-mail address: hozouri.m.u@gmail.com (M. Hozouri) 
which refers to undocumented, oral and unwritten words confirmed by no one. Also, organizational rumors influence on organizational commitment and change it. Such associations among variables motivated authors to express explicit and implicit functions in addition to explain such concepts as organizational silence, organizational commitment and organizational rumors. Finally, the impact of organizational silence on organizational commitment is studied with or without considering organizational rumors.

\section{Problem description}

Today, the concern of managers is to commit the employees to organizational goals and, in this vein, they make all efforts to make them more committed. Some managers believe that they can make their employees more committed by contributive management in order to minimize such destructive behaviors as turnover, attendance, hardiness and absenteeism while some managers create a climate of suspicious and distrust which causes that employees do not feel safe in interactions with their managers and refuse to share their ideas which would foster organizational silence (Liu et al., 2009) and reduce the level of organizational commitment. On this basis, organizational silence is a component which can impact on organizational commitment. As indicated by Morrison and Milliken (2000), the consequences of organizational silence can include cognitive incompatibility which leads into reduction in motivation, commitment and satisfaction (Morrison \& Milliken, 2000). On the other hand, communication is an issue which facilitates to achieve organizational predetermined goals (Zagenczyk et al., 2008). This happens in two official and unofficial modes. Rumors are increasing in organizations with unofficial communications. Such rumors occur in organizations dominated by silence atmosphere without official communication channels since employees tend to communicate, express their ideas, problems and job difficulties so unofficial communication channels are created and changes occur in organizational commitment.

\section{Literature review}

\subsection{Organizational commitment}

An issue paid attention by authors is different aspects of commitment concept since employees' dependency and commitment relates to not only organization but also other profession, family, immediate supervisor, etc. (Abtahi \& Molaee, 2007). Employees' commitment to organization generates invisible assets. In other words, one can consider employees' commitment as a goal rather than a tool (Kermani, 2011). In early 1980s, employees' organizational commitment was an important issue paid attention by many authors and paramount researches were done in this regard (Kabiri et al., 2006). Kozlowski and Klein (2000) also pointed out the importance of commitment and stated "the lack of commitment is more dangerous that what called lack of ethics. Lack of commitment overshadows organization and can mitigate effectiveness almost all operations" (Fang, 1984). However, it is hard to define commitment and there is a low concurrence on its nature. Often, commitment is defined as tendency to keep a relationship. Sometimes, it is defined as obligation by someone to others. Recently, commitment is defined as resistance against change. This term is rooted in determining the identity, common values, belongings, dedication and homology (Fullerton, 2003). Put it differently, one can say that commitment is to dedicate oneself or a part of it for a certain target (Kabiri et al., 2006). Commitment as a desired professional value is generated through initial works on professional features. Interest on professional commitment is generated more by Gouldner (1960) who identified a dichotomy between commitment to organization and professional commitment for professional people in bureaucratic organizations (Tayler, 1988). Porter defines organizational commitment as accepting organizational values and involvement in organization. Likewise, others defined organizational commitment as an affective support and association to organizational goals and values to realize other goals (Rezayimanesh \& Kermanshahi, 2010).

According to Abtahi and Molaee (2007) professional commitment is the feeling of identity and dependency to a certain job and profession and emphasizes on tendency and interest to work in a profession as professional commitment. Professional commitment refers to people's dependency to their professions. 
In fact, professional commitment is to believe in professional goals and values and their beliefs and tendency to show a remarkable effort on profession and membership maintenance in profession (Elias, 2006). Allen and Meyer (1993) considered three emotional, continuous and normative aspects for professional commitment and defined professional commitment as the feeling of identity by a profession, need to continue services in a job and feeling of high responsibility on it (Osinsky \& Meuller, 2004).

\subsubsection{The advantages of professional and organization commitment}

Professional commitment is associated with important outputs like job performance improvement, turnover intentions reduction and more satisfaction in both organizational and professional levels (Elias, 2006). Relevant studies indicate that high levels of employees' professional commitment would yield to more motivation and satisfaction and would mitigate the possibility of organizational turnover. Professional commitment more likely influences on people's job behaviors such as their visible attitudes, their judgments on ending the job, job engagement and their contribution in professional groups. Professional commitment relates to positive behaviors fruitful for organization and people with higher levels of professional commitment are less involved in operations harmful for organization (Greenfield et al., 2008).

\subsection{Organizational silence}

Competent and capable employees are huge capitals for any organization. To succeed, organizations should ask their human capitals to be innovative, to state on different issues and have the feeling of responsibility. Employees' different, various and even conflicted viewpoints are important for organizational effective decision makings. However, the results of field studies indicate that employees often feel that they are enforced to be silent in facing with concerns or difficulties (Morrison \& Milliken, 2000). Today, scientists' minds are occupied by this question that whether being silent is good or not. Initial definitions of silence are equal to loyalty so that if there are no words on problems, which means that there is no interference. However, authors have also indicated that silence climate can prevent desired return for organization (Shojaie et al., 2011: 1732). Silence is related to many realities such as humility, respecting the others, caution, courtesy, etc. (Perlow \& Williamson, 2003). Morrison and Milliken (2000) believe that organizational silence is emanated in personal silence or the silence of all organizational employees and when most organizational members are silent for different organizational problems, silence becomes a collective behavior so-called organizational silence. Findings by Brinsfield et al. (2009) suggest that organizational silence is prevalent, multidimensional, measurable and highly related to other important phenomena of organizational behavior. Morrison and Milliken (2000) target organizational silence as a chain between silence and voice and explain silence behavior though different organizational climate. According to them, organizational silence yields to the feeling of no valuing, lack of conceived control and lack of agreement which leads into reduction in satisfaction, commitment and motivation. Likewise, Oliver (1990) argues that abovementioned factors influence on job turnover, stress level and job efforts; here, the concept of commitment differs from job satisfaction. Morrison and Milliken (2000) defined organizational silence as a "collective phenomenon" and employees' propensity to not disclose their ideas and concerns on organizational problems and difficulties (Vakola and Bourdas, 2005: p. 441). They believe that "Why silence?" roots in workplace sociology not all employees' psychology. Through organizational climate, employees understand that speaking and providing their opinions is worthless and dangerous or valuable and safe (Vakola \& Bouradas, 2005, p. 226). Vakola and Bouradas (2005) defined organizational silence as "employees' general refusal on expressing their ideas and information on job".

\subsubsection{Types of silence}

In a research, different types of silence are mentioned. This typology includes absolute silencing, revisionist silencing and selective silencing. 
Absolute silencing: some managers say that they should say nothing to others about their activities in organization. One excessive type is absolute silencing. Overall, the impact of such strategy is that organization ignores organizational members' affective needs and their needed resources.

Revisionist silencing: managers say that they will rewrite their supportive activities as more traditional activities in workplace.

Selective silencing: this type of silencing also achieves similar results to absolute and revisionist silencing. It protects organization against personal hardness and problems. Discussion on such positive behaviors allow managers to shape their workplace identity and to support them (McGowan, 2003, p. 4). Table 1 outlines a summary of types of silence.

Table 1

A summary of types of silence

\begin{tabular}{lc}
\hline Description & Type \\
\hline Ab excessive type of silencing posed by management & Absolute silencing \\
Rewriting workplace supportive activities & Revisionist silencing \\
Shaping workplace identity by management & Selective silencing \\
\hline
\end{tabular}

\subsection{Organizational rumors}

As an unethical behavior among organizational employees, rumor is defined as information transmitted through a grapevine that its impact is determined by stress level of those people who hear it (DiFonzo \& Bordia, 2000; Rosnow \& Fine, 1976). On the contrary to their long term validity, as unreliable predictors, rumors can impact on predicting the behaviors (Difonzo \& Bordia, 2002). Rumors are unreal information disseminated through word-of-mouth or other complicated patterns. Accepted concept of rumor is that it is an interpersonal interaction to which there is no evidence on its rightness or reality (Michelson \& Mouly, 2000). Rumor is a collective job in which non-confirmed news are expressed by a group of people so that it is accepted by public (Jandaghi et al., 2012). Knapp (1994) defines rumor as a "status on believing an issue disseminated without official confirmation." Peterson and Gist (1951) studied rumor and public opinions and explained rumor as "a non-confirmed definition on events disseminated among people which causes public concerns on an issue or event". Michelson and Mouly (2000) described rumor as "unofficial exchanged communication s with others without considering whether it is based on reality or not." Hayakawa (2002) defines rumor as a kind of social events by which a similar statement is published in a big scale and in short term through communicative chains. Likewise, Shibutani (1966) defines rumor as collective problem solution by which people are involved in important conditions and attempt to infer meaningful descriptions by gathering mental resources. Table 2 outlines a summary of provided definitions on rumor.

Table 2

Definitions of rumors

\begin{tabular}{ccc}
\hline Author & Year & Definition \\
\hline Rosnow \& Fine & 1976 & Transmitted information from unofficial communication networks \\
Knapp & 1994 & Believing an issue without its official confirmation \\
Shibutani & 1966 & Attempts to gather mental resources through meaningful deductions and descrip- \\
tions
\end{tabular}

\subsection{Rumor producing factors}

Producing and disseminating rumors in a society and among the audiences needs a proper context and factors which accelerate such process. These factors include: 
- $\quad$ The intensity of affective emotions and tensions

- Information gap

- $\quad$ Work deception and deviation motivations

- $\quad$ Threatening motivation

- $\quad$ Hidden and revealed hostility

- $\quad$ Curiosity

- $\quad$ Making others happy

\section{The proposed study}

The purpose of this study is to investigate the status of organizational silence components, organizational rumors and organizational commitment. It also tries to study the impacts of organizational silence on organizational commitment by considering organizational rumors. Considering theoretical basics and international literature, a conceptual model is drawn. On this basis, organizational silence is considered as independent variable, organizational commitment as dependent variable and organizational rumors as mediating variable. Fig. 1 outlines research conceptual model.

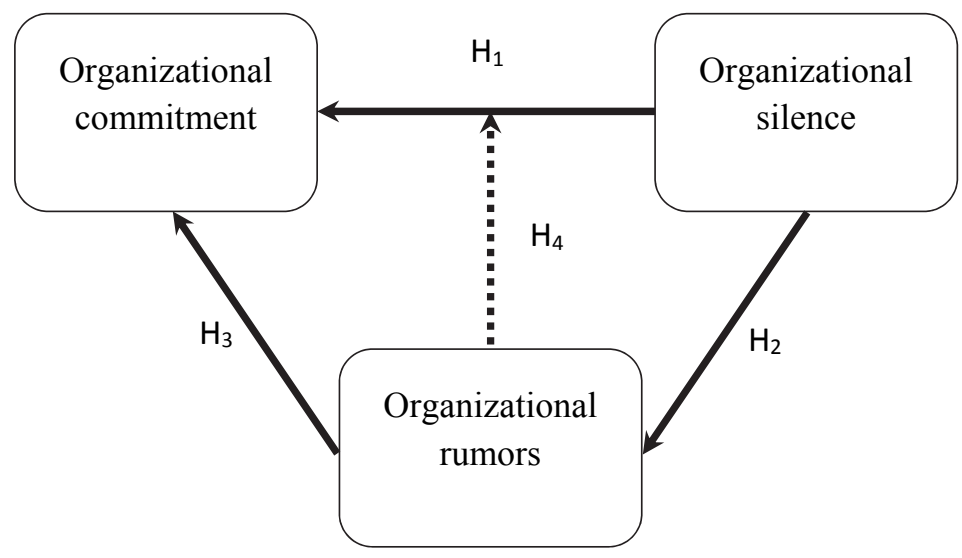

Fig. 1. The conceptual model of the proposed method

Based on the structure of the proposed study shown in Fig. 1, the following hypotheses are considered.

- There is a relationship between organizational silence and organizational commitment.

- There is a relationship between organizational silence and organizational rumors.

- There is a relationship between organizational rumors and organizational commitment.

- Organizational rumors impact on the relationship between organizational silence and organizational commitment

This is a survey-type descriptive research and a subset of correlation studies. Its spatial scope involves all employees In Municipality. In autumn 2011, questionnaires were distributed among research population including all employees in Municipality. Finally, 50 questionnaires were used for analyses. Before distribution, the validity of the questionnaire was studied by a group of experts and connoisseurs in Municipality and then, their proposed amendments were made. Upon distributing a 30-subject sample of organizational silence questionnaires, organizational rumors and organizational commitment in research population, the reliability of questionnaires were computed as $0.681,0.853$ and 0.742 for organizational silence, organizational rumors and organizational commitment, respectively. Considering these ratios and the fact that all of them are over 0.6 , the reliability of questionnaires is supported. 


\section{Research findings}

Based on descriptive statistics, $16 \%$ and $84 \%$ of sample are female and male, respectively. In terms of education, $32 \%$ have high school diploma, $14 \%$ have associate of arts, $42 \%$ have bachelor's degree and $12 \%$ have master's degree or higher degrees. In terms of job experience, $18 \%$ had less than five years of job experience, $26 \%$ maintained between five and fifteen years, $38 \%$ fifteen to twenty-five years and $18 \%$ had more than twenty-five years of job experience. In terms of employment status, $58 \%$ were formal, $24 \%$ were contractual and $18 \%$ were listed in other categories. Table 3 outlines descriptive statistics on organizational silence, organizational rumor and organizational commitment variables.

\section{Table 3}

Descriptive statistics on research variables

\begin{tabular}{lcccccc}
\hline Statistical variable & Quantity & Minimum & Maximum & Average & Standard deviation & Status \\
\hline Organizational commitment & 50 & 2.13 & 6.2 & 4.727 & 0.87 & Desired \\
Organizational silence & 50 & 1 & 7 & 3.986 & 1.153 & Desired \\
Organizational rumors & 50 & 1.5 & 7 & 4.176 & 1.439 & Desired \\
\hline
\end{tabular}

Utilized range in present study is Likert seven-scale in which the average 4 is considered as the border between desired and undesired status. Considering the nature and the content of organizational commitment, such average is desired for organizational commitment. Also, considering the increase in the average of organizational silence which means its extension in organization and the fact that it is less than 4 in Municipality, one can say that organizational silence status is almost suitable. It means that employees in Municipality are less tended to organizational silence and silence climate is less dominated in this organization. This is also true for organizational rumors. In the case that the average is higher than 4 , it means that more rumors are common in organization. Since relevant data are quantified, we use Pearson correlation coefficient to examine the relations among variables. On this basis, relevant results are outlined in Table 4.

\section{Table 4}

The results on correlations among variables

\begin{tabular}{|c|c|c|c|c|}
\hline Variables & & $\begin{array}{c}\text { Organizational } \\
\text { commitment }\end{array}$ & $\begin{array}{c}\text { Organizational } \\
\text { silence }\end{array}$ & $\begin{array}{c}\text { Organizational } \\
\text { rumors }\end{array}$ \\
\hline \multirow{2}{*}{$\begin{array}{c}\text { Organizational com- } \\
\text { mitment }\end{array}$} & $\begin{array}{l}\text { Correlation coef- } \\
\text { ficient }\end{array}$ & 1 & $-0.449^{* *}$ & $-0.357^{*}$ \\
\hline & Significance & - & 0.001 & 0.011 \\
\hline \multirow{2}{*}{$\begin{array}{l}\text { Organizational si- } \\
\text { lence }\end{array}$} & $\begin{array}{l}\text { Correlation coef- } \\
\text { ficient }\end{array}$ & - & 1 & $0.788^{* *}$ \\
\hline & Significance & - & - & 0 \\
\hline \multirow{2}{*}{$\begin{array}{l}\text { Organizational ru- } \\
\text { mors }\end{array}$} & $\begin{array}{l}\text { Correlation coef- } \\
\text { ficient }\end{array}$ & - & - & 1 \\
\hline & Significance & - & - & - \\
\hline
\end{tabular}

Table 5 indicates that organizational commitment maintains a negative and meaningful relationship with organizational silence and organizational rumors. This means that increasing organizational silence or organizational rumors in Municipality would decrease organizational commitment and vice versa. On the other hand, there is a direct significant relationship between organizational silence and organizational rumors and their changes are in the same direction. It means that increasing organizational silence among the employees of Municipality and increasing silence climate by managers would lead into more organizational rumors among employees. Table 5 presents the relationship between organizational commitment and organizational silence by considering organizational rumors. 
Table 5

The relationship between organizational commitment and organizational silence through controlling organizational rumors

\begin{tabular}{lllll}
\hline $\begin{array}{l}\text { Controlled } \\
\text { variable }\end{array}$ & Variables & & $\begin{array}{l}\text { Organizational } \\
\text { commitment }\end{array}$ & $\begin{array}{l}\text { Organizational } \\
\text { silence }\end{array}$ \\
\hline \multirow{2}{*}{$\begin{array}{l}\text { Organizational ru- } \\
\text { mors }\end{array}$} & $\begin{array}{l}\text { Organizational } \\
\text { commitment }\end{array}$ & $\begin{array}{l}\text { Correlation } \\
\text { coefficient } \\
\text { Significance }\end{array}$ & - & -0.291 \\
\cline { 2 - 5 } & $\begin{array}{l}\text { Organizational } \\
\text { silence }\end{array}$ & $\begin{array}{l}\text { Correlation } \\
\text { coefficient } \\
\text { Significance }\end{array}$ & - & 0.042 \\
\hline
\end{tabular}

Table 5 indicates that there is still a reverse significant relationship between organizational commitment and organizational silence. However, such relationship is not fostered by controlling organizational rumors, rather, it is weakened. This means that some impacts of organizational silence on organizational commitment are decreased through organizational rumors while some organizational commitment changes are due to the impacts of organizational rumors. So, organizational rumor is a variable which influence on the relationship between organizational silence and organizational commitment and enhances their reverse relationship. Finally, Table 6 shows that to some extent, organizational commitment can be predicted by organizational silence and organizational rumors. On this basis, $20 \%$ and $13 \%$ of organizational commitment changes can be predicted and pursued by organizational silence and organizational rumors respectively.

Table 6

The rations of organizational commitment changes

\begin{tabular}{ccccc}
$\begin{array}{l}\text { Statistical variable } \\
\text { Independent variable }\end{array}$ & $\mathbf{R}$ & R-Square & $\begin{array}{c}\text { Adjusted } \\
\text { R-Square }\end{array}$ & $\begin{array}{c}\text { Std. Error of the } \\
\text { Estimate }\end{array}$ \\
\hline Organizational silence & 0.449 & 0.201 & 0.185 & 0.78588 \\
Organizational rumors & 0.357 & 0.127 & 0.109 & 0.82143 \\
\hline
\end{tabular}

\section{Conclusion and recommendations}

In organizations dominated by organizational silence or silence atmosphere, employees are reluctant to establish official communications. Since people need to communicate in order to express their opinions, ideas and job and even personal problems, they recourse to unofficial communication channels especially rumors in organization and express their opinions, viewpoints, insights and even feeling. On this basis, organizational silence can be an affecting factor on organizational rumors. As indicated by Morrison and Milliken (2000), organizational silence can impact on employees' organizational commitment and can change the extent of employees' organizational commitment. In addition to organizational silence, organizational rumors also influence on organizational commitment. As a behavioral phenomenon, organizational rumor is a subset of communication discussion and organizational rumors are raised when they happen in unofficial context out of organizational scope. Employees' organizational commitment changes if there are many rumors in organization. Positive or negative changes in organizational commitment depends on constructive or destructive content of the message disseminated by word-of-mouth. Research conceptual model was designed by abovementioned issues and the relationship and impacts of organizational silence of organizational commitment were analyzed either independently or through organizational rumors. The findings indicate that the status of organizational commitment and organizational silence were in desired level while the status of organizational rumor was not in desired level. 
Likewise, initial findings indicate that without controlling organizational rumors variable, there was a reverse relationship between organizational commitment with organizational silence and organizational rumors. Under the same circumstances, there was a direct relationship between organizational silence and organizational rumors. It means that increasing employees' organizational silence and intensifying silence climate would increase organizational rumors and vice versa.

Supplementary results indicate that by controlling organizational rumors, there is still a reverse relationship between organizational commitment and organizational silence. It means that increasing organizational silence would decrease employees' organizational commitment. Based on above points, below recommendations are provided:

1. Organizational managers should attempt to make organizational employees' communication structured and systematic.

2. The establishment of organizational unofficial groups should be normative to prevent organizational rumors.

3. Unofficial communications should become structured and systematic. It means that any issue should not be raised in communications.

4. Managers should listen to employees' ideas, viewpoints, insights and grievances and do not take against them.

5. Organizational silence climate should be changed to supportive one so that employees are encouraged to speak since their minds will be blocked if the tongues stop talking.

6. Employees' organizational commitment plans and obliging employees to values, beliefs and norms should be seriously monitored and pursued.

\section{Acknowledgement}

The authors would like to thank the anonymous referees for constructive comments on earlier version of this paper

\section{References}

Abtahi, S. H., \& Molaee, N. (2007). The relationship between professional and organizational commitment. Tadbir Journal, 177.

Allen, N. J., \& Meyer, J. P. (1993). Organizational commitment: evidence of career stage effects? Journal of Business Research, 26(1), 49-61.

Brinsfield, C. T., Edwards, M. S., \& Greenberg, J. (2009). Voice and silence in organizations: Historical review and current conceptualizations. Voice and silence in organizations, 1.

DiFonzo, N., \& Bordia, P. (2000). How top PR professionals handle hearsay: Corporate rumors, their effects, and strategies to manage them. Public Relations Review, 26(2), 173-190.

DiFonzo, N., \& Bordia, P. (2002). Rumors and stable-cause attribution in prediction and behavior. Organizational Behavior and Human Decision Processes, 88(2), 785-800.

Elias, R. Z. (2006). The impact of professional commitment and anticipatory socialization on accounting students' ethical orientation. Journal of Business Ethics, 68(1), 83-90.

Fullerton, G. (2003). When does commitment lead to loyalty?. Journal of Service Research, 5(4), 333344.

Gouldner, H. P. (1960). Dimensions of organizational commitment. Administrative Science Quarterly, 4(4), 468-490.

Greenfield, A. C., Norman, C. S., \& Wier, B. (2008). The effect of ethical orientation and professional commitment on earnings management behavior. Journal of Business Ethics, 83(3), 419-434.

Hayakawa, H. (2002). Ryugen no shakaigaku—keishikisyakaigaku karano sekkin (sociology of rumor approach from formal sociology). Seikyusya, Tokyo, Japan. 
Fang, R. J. (1984). Developing a model for analyzing administrators' professional commitment in pennsylvania postsecondary vocational technical schools. Final report. Vocational-technical education research report, Vocational-Technical Education Research Report, 22(3), n3.

Jandaghi, G., Bordbar, H., \& Jangholi, M. (2012). Clarifying ethical constituents of God-believing employees to mitigate the outcomes of rumors and organizational rumor management. International Journal of Human Resource Studies, 2(1), 100.

Kabiri, A., Khodayari, I., Moradi, M., \& Nazari, F. (2006), Studying the relationship between transactional and transformational leadership styles and organizational commitment. Management Culture Journal, 4, 117-142.

Kermani, B. (2011). The relationship between personal / professional traits and organizational commitment. Homaye Salamat, 38, 32-37.

Kozlowski, S. W., \& Klein, K. J. (2000). A multilevel approach to theory and research in organizations: Contextual, temporal, and emergent processes.

Knapp, R. H. (1944). A psychology of rumor. Public Opinion Quarterly, 8(1), 22-37.

Liu, D., Wu, J., \& Ma, J. C. (2009, July). Organizational silence: A survey on employees working in a telecommunication company. In Computers \& Industrial Engineering, 2009. CIE 2009. International Conference on(pp. 1647-1651). IEEE.

McGowan, R. A. (2003, July). Organizational discourses: sounds of silence. In 3rd International Critical Management Studies Conference LancasterUniversity (pp. 1-7).

Michelson, G., \& Mouly, S. (2000). Rumour and gossip in organisations: a conceptual study. Management Decision, 38(5), 339-346.

Morrison, E. W., \& Milliken, F. J. (2000). Organizational silence: A barrier to change and development in a pluralistic world. Academy of Management review, 25(4), 706-725.

Mowday, R. T., Porter, L. W., \& Steers, R. M. (2013). Employee-organization linkages: The psychology of commitment, absenteeism, and turnover. Academic press.

Oliver, N. (1990). Rewards, investments, alternatives and organizational commitment: Empirical evidence and theoretical development. Journal of Occupational and Organizational Psychology, 63(1), 19-31.

Osinsky, P., \& Mueller, C. W. (2004). Professional commitment of Russian provincial specialists. Work and Occupations, 31(2), 193-224.

Perlow, L., \& Williams, S. (2003). Is silence killing your company?. Ieee Engineering Management Review, 31(4), 18-23.

Peterson, W. A., \& Gist, N. P. (1951). Rumor and public opinion. American Journal of Sociology, 57(2), 159-167.

Rezayimanesh, B., \& Kermanshahi, S. (2010). The relationship between spirituality and organizational commitment in workplace. Strategic Management Researches, 46, 89-112.

Rosnow, R. L., \& Fine, G. A. (1976). Rumor and gossip: The social psychology of hearsay. Elsevier.

Shibutani, T. (1966). Improvised News: A Sociological Study of Rumor, Bobbs-Merrill, Indianapolis. America.

Shojaie, S., Matin, H. Z., \& Barani, G. (2011). Analyzing the infrastructures of organizational silence and ways to get rid of it. Procedia-Social and Behavioral Sciences, 30, 1731-1735.

Tayler, L.E. (1988). Professional commitment: the influence of the processes socialization and professionalization and selected socio-demographic factors in Canadian social work. University of Toronto.

Vakola, M., \& Bouradas, D. (2005). Antecedents and consequences of organisational silence: an empirical investigation. Employee Relations, 27(5), 441-458.

Zagenczyk, T. J., Gibney, R., Murrell, A. J., \& Boss, S. R. (2008). Friends don't make friends good citizens, but advisors do. Group \& Organization Management, 33(6), 760-780.

Zehir, C., \& Erdogan, E. (2011). The association between organizational silence and ethical leadership through employee performance. Procedia-Social and Behavioral Sciences, 24, 1389-1404.

Zhang, Z. L., \& Zhang, Z. Q. (2009). An interplay model for rumour spreading and emergency development. Physica A: Statistical Mechanics and its Applications, 388(19), 4159-4166. 
C 2018 by the authors; licensee Growing Science, Canada. This is an open access article distributed under the terms and conditions of the Creative Commons Attribution (CCBY) license (http://creativecommons.org/licenses/by/4.0/). 